\title{
Rapid plant DNA and RNA extraction protocol using a bench drill
}

\section{Brief Note}

\author{
C.F. Ferreira $^{1^{*}}$, D.L. Gutierrez ${ }^{2 *}$, J.F. Kreuze ${ }^{3}$, M.L. Iskra-Caruana ${ }^{4,5}$, \\ M. Chabannes ${ }^{4,5}$, A.C.O. Barbosa ${ }^{6}$, T.A. Santos ${ }^{6}$, A.G.S. Silva ${ }^{6}$, \\ R.M.F. Santos ${ }^{7}$, E.P. Amorim ${ }^{1}$, S.A.S. de Oliveira ${ }^{1}$ and O.N. Jesus ${ }^{1}$ \\ ${ }^{1}$ Embrapa Mandioca e Fruticultura, Cruz das Almas, BA, Brasil \\ ${ }^{2}$ INIA - Instituto Nacional de Innovación Agraria, La Molina, Lima, Peru \\ ${ }^{3}$ CIP - Centro Internacional de la Papa, Lima, Peru \\ ${ }^{4}$ CIRAD, UMR BGPI, F-34398, Montpellier, France \\ ${ }^{5}$ BGPI, CIRAD, Univ. Montpellier, INRA, Montpellier SupAgro, \\ Montpellier, France \\ ${ }^{6}$ Universidade Federal do Recôncavo da Bahia, Cruz das Almas, BA, Brasil \\ ${ }^{7}$ Universidade Estadual de Feira de Santana, Feira de Santana, BA, Brasil \\ * These authors contributed equally to this study.
}

Corresponding author: C.F. Ferreira

E-mail: claudia.ferreira@embrapa.br

Genet. Mol. Res. 18 (3): gmr18394

Received June 12, 2019

Accepted July 18, 2019

Published August 14, 2019

DOI http://dx.doi.org/10.4238/gmr18394

\begin{abstract}
Plant DNA and RNA extraction methods are well established, with a wide range of protocols, depending on the purposes of each laboratory/research. Nowadays, quick, inexpensive and easy plant DNA and RNA extraction methods are highly sought after. We developed an optimized protocol for plant DNA and RNA extraction that uses an inexpensive bench drill and plastic bags and does not require liquid nitrogen. DNA from leaves and RNA from leaves and roots of banana, pineapple, citrus, papaya, passion fruit and cassava, were extracted using a basic cetyltrimethylammonium bromide method. Both nucleic acids were quantified and evaluated for quality based on agarose gel electrophoresis. The DNA and RNA extractions were successful for all species, and RNA quality in pellets was maintained after storage at room temperature for three weeks. This protocol can reduce costs considerably in laboratories with ongoing routine activities of DNA and
\end{abstract}


RNA extraction for genetic diversity and gene expression analyses, where other conventional methods have not been successful due to explant, condition of samples and quantity and quality of nucleic acids. This is especially relevant for many laboratories in developing countries where the cost and availability of liquid nitrogen may be a constraint.

Key words: Inexpensive; Plant nucleic acids extraction; RNA pellet viability

\section{INTRODUCTION}

Most plant DNA and RNA extraction protocols available make use of liquid nitrogen as the main component to disrupt the cell wall and give access to these molecules. However, liquid nitrogen can be expensive, hindering the extraction of a large number of samples, mainly due to its availability and cost and depending on each laboratory conditions and budget.

Although there are various published protocols that do not use liquid nitrogen (Ferdous et al., 2012, Sahu et al., 2012), our protocol makes use of a low cost bench drill to substitute the liquid nitrogen to hasten extraction and cheap plastic bags instead of mortar and pestle, yielding large quantities of high quality DNA and RNA from leaves and roots of a variety of tropical plant species. This protocol can be used for extraction of both DNA and RNA of plants, and while usually nucleic acid extraction by other protocols makes use of mortar and pestle, this protocol eliminates the differences in the amount and quality of nucleic acids extracted providing homogeneity in samples since the same force (drill) is applied. Furthermore, in samples with high water content and in woody samples, maceration using mortar and pestle is hindered due to formation of ice crystals whereas this problem is overcome by homogenizing samples using a drill. Also, most RNA extraction protocols require expensive kits and laboratory equipment, such as a refrigerated centrifuge, which is not necessary with the use of this protocol. It also delivers good quality RNA that can maintained at room temperature for at least three weeks.

The round shape of the Biorema drill $\left(\operatorname{Agdia}^{\circledR}\right)$ facilitates homogenization of the sample. It is made of an aluminum steel rod with a $4 \mathrm{~cm}$ diameter bottom, with ten ball bearings of approximately $0.5 \mathrm{~cm}$ diameter each around its circumference, attached to the drill bit. This protocol can be used in a laboratory with minimal conditions and equipment, since it does not require the use of a refrigerated centrifuge during the different steps, and is best recommended for fresh samples that were not stored at $-80^{\circ} \mathrm{C}$, or were not subjected to ultra-low temperatures during the collection procedure. Moreover, samples can be easily stored in a simple freezer ($18^{\circ} \mathrm{C}$ ) for 3 - 4 days prior to nucleic acid extraction.

Due to the instability of the RNA molecule and sometimes the need for transportation to other institutions (for high-throughput sequencing HTS - analysis, for example), which may take days or weeks, the shelf life of RNA pellets is a relevant concern.

\section{MATERIAL AND METHODS}

DNA and RNA from leaves of banana, passion fruit, papaya, citrus, pineapple and cassava, and RNA from roots of banana, citrus, pineapple and cassava, were extracted using a bench drill. Young leaves and roots of most of the tropical plants mentioned above were collected from the germplasm bank at Embrapa Mandioca e Fruticultura located in Cruz das Almas, Bahia, Brazil. DNA and RNA of three plant genotypes per species (with three replicates per genotype), were extracted using the CTAB (cetyltrimethylammonium bromide) protocol 
(Doyle and Doyle, 1990) protocol and the CIP - CTAB protocols (see below) for DNA and RNA extractions, respectively. In both cases, the first step of the protocol was modified with the use of plastic bags $\left(20 \times 10 \times 0.01 \mathrm{~cm}\right.$ - virgin low-density polyethylene - Bahia Embalagem ${ }^{\circledR}$ - or any other supplier that offers the same specifications) and a drill to grind plant tissues inside the plastic bags at rotation of $2500 \mathrm{rpm}$ until tissue is fully dissolved. The drill bit can be cleaned with $70 \%$ alcohol for each sample change. The drill at this rotation in contact with bags with the specifications above, will not damage the bag, however, two bags (inside each other) may be used if suited. Two mL of extraction buffer $(2 \%$ CTAB, $100 \mathrm{mM}$, Tris- $\mathrm{HCl}, \mathrm{pH} 8.0,50 \mathrm{mM}$ EDTA, pH 8.0 . 1.4 M NaCl, 2\% PVP-40 - add before use and 1\% Na sulfite add before use) were added in plastic bags containing $300 \mathrm{mg}$ of leaf tissue and macerated by using Biorema drill (Agdia®) (Figure 1).
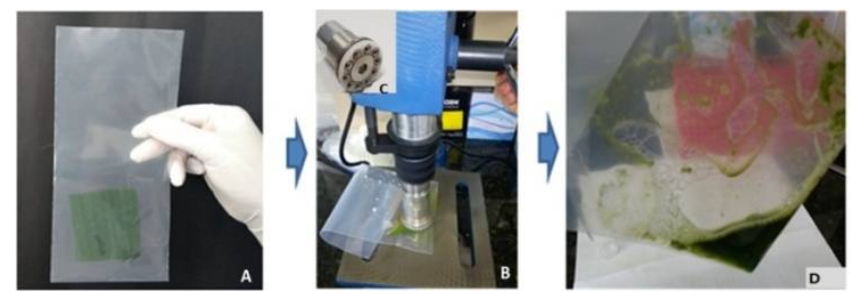

Figure 1. A: Plastic bag $(20 \times 10 \times 0.01 \mathrm{~cm})$ used for the bench drill maceration with banana leaf sample $(5 \times 5 \mathrm{~cm})$; B: Bench drill maceration of the sample in the plastic bag with $2 \mathrm{~mL}$ of extraction not, maceration buffer; C: Biorema drill (Agdia $\left.^{\circledR}\right)$; D: Macerated leaf sample with extraction buffer.

Evaluation of quality and quantity of DNA was carried out on $0.8 \%$ agarose gel stained with ethidium bromide $\left(0.5 \mathrm{mg} \cdot \mathrm{mL}^{-1}\right)$. DNA purity values averaged at approximately 1.863 to 2.000 at A260/A280 and A260/A230, respectively. Quantification was estimated by comparison of bands with known aliquots of standard concentration (DNA-Lambda Sigma) and samples adjusted to $150 \mathrm{ng} . \mu \mathrm{L}^{-1}$ (Figure 2).

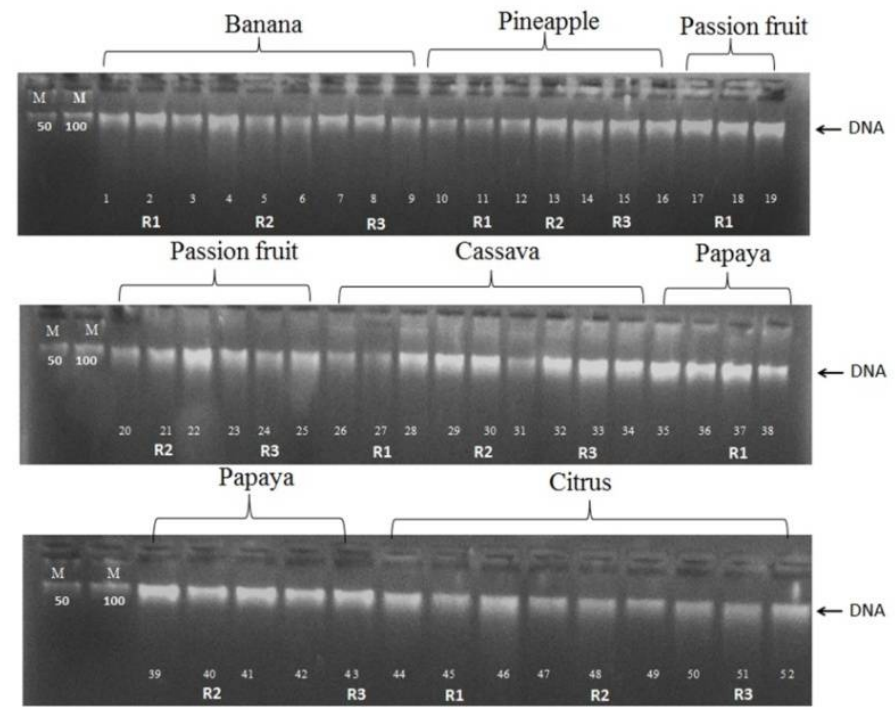

Figure 2. Eletrophoretic profile of DNA extracted from leaves of six plant species (banana, pineapple, passion fruit, cassava, papaya, citrus) for three different genotype of each species (R1, R2 and R3) using the bench drill protocol. The concentration was adjusted to $150 \mathrm{ng} \cdot \mu \mathrm{L}^{-1}$ for each sample and samples were run on $0.8 \%$ agarose gel. $50=50 \mathrm{ng} \cdot \mu \mathrm{L}^{-1}$ and $100=100 \mathrm{ng} \cdot \mu \mathrm{L}^{-1}$ markers. 
To confirm the quality of the extracted DNA, DNA of each species (three replicates of three different genotypes for each species) was amplified by PCR using five inter simple sequence repeat (ISSR) markers and five simple sequence repeat (SSR) markers (Tables 1 and 2; Figure 2), in a total volume of $15 \mu \mathrm{L}$ containing: $30 \mathrm{ng}$ of DNA, $0.2 \mathrm{mM}$ primer, $2 \mathrm{mM} \mathrm{MgCl} 2,0.2 \mathrm{mM}$ dNTP, $1 \times$ Tris HCL buffer and 1 unit of Taq. The following amplification program was used: $94^{\circ} \mathrm{C}$ for $3 \mathrm{~min}$. and 35 cycles of $94^{\circ} \mathrm{C}$ for $30 \mathrm{~s}, \mathrm{x}^{\circ} \mathrm{C}$ for $30 \mathrm{~s}, 72^{\circ} \mathrm{C}$ for $45 \mathrm{~s}$ and a final extension at $72^{\circ} \mathrm{C}$ for $5 \mathrm{~min}$. then $14^{\circ} \mathrm{C}$ forever $\left(\mathrm{x}=\right.$ Ta: for all ISSRs was $49^{\circ} \mathrm{C}$ and SSR varied from 50 to $60^{\circ} \mathrm{C}$ ) (Tables 1 and 2).

\begin{tabular}{|c|c|c|c|c|c|}
\hline Species & Name ISSR & $5^{\prime}-3^{\prime}$ & Species & ISSR Name & $5^{\prime}-3^{\prime}$ \\
\hline Banana & $\begin{array}{l}\text { (1) DiCA } \\
\text { (4)DiCA3'T } \\
\text { (7)DiCA5'CY } \\
\text { (10)DiGA } \\
\text { (17)DiGA5'CY }\end{array}$ & $\begin{array}{l}\text { CACACACACACACACA } \\
\text { CACACACACACACACAT } \\
\text { CYCACACACACACACACA } \\
\text { GAGAGAGAGAGAGAGA } \\
\text { CYGAGAGAGAGAGAGAGA }\end{array}$ & Cassava & $\begin{array}{l}\text { (18)DiGA5'T } \\
\text { (35)TriCAG3'YC } \\
\text { (71)TriTCT 3'RC } \\
\text { (74)TriTGA 3'RC } \\
\text { (35)TriCAC5'CR }\end{array}$ & $\begin{array}{l}\text { TGAGAGAGAGAGAGAGA } \\
\text { CAGCAGCAGCAGCAGYC } \\
\text { TCTTCTTCTTCTTCTRC } \\
\text { TGATGATGATGATGARC } \\
\text { CRCACCACCACCACCAC }\end{array}$ \\
\hline Citrus & $\begin{array}{l}\text { (7)DiCA5'CY } \\
\text { (8)DiCA5'G } \\
\text { (11)DiGA3'C } \\
\text { (15)DiGA5'C } \\
\text { (22)DiGT3'RG }\end{array}$ & $\begin{array}{l}\text { CYCACACACACACACACA } \\
\text { GCACACACACACACACA } \\
\text { GAGAGAGAGAGAGAGAC } \\
\text { CGAGAGAGAGAGAGAGA } \\
\text { GTGTGTGTGTGTGTGTRG }\end{array}$ & Papaya & $\begin{array}{l}\text { (7)DiCA5'CY } \\
\text { (8)DiCA5'G } \\
\text { (9)DiCA5'T } \\
\text { (10)DiGA } \\
\text { (11)DiGA3'C }\end{array}$ & $\begin{array}{l}\text { CYCACACACACACACACA } \\
\text { GCACACACACACACACA } \\
\text { TCACACACACACACACA } \\
\text { GAGAGAGAGAGAGAGA } \\
\text { GAGAGAGAGAGAGAGAC }\end{array}$ \\
\hline $\begin{array}{l}\text { Passion } \\
\text { fruit }\end{array}$ & $\begin{array}{l}\text { (17)DiGA5'CY } \\
\text { (31)TriCAC5'CR } \\
\text { (32)TriCAC5'CY } \\
\text { (70)TriTCA 3'RC } \\
\text { (72)TriTCC 3'RC }\end{array}$ & $\begin{array}{l}\text { CYGAGAGAGAGAGAGAGA } \\
\text { CRCACCACCACCACCAC } \\
\text { CYCACCACCACCACCAC } \\
\text { TCATCATCATCATCARC } \\
\text { TCCTCCTCCTCCTCCRC }\end{array}$ & Pineapple & $\begin{array}{l}\text { (3)DiCA3'RG } \\
\text { (5)DiCA3'YG } \\
\text { (11)DiGA3'C } \\
\text { (19)DiGT } \\
\text { (21)DiGT3'C }\end{array}$ & $\begin{array}{l}\text { CACACACACACACACARG } \\
\text { CACACACACACACACAYG } \\
\text { GAGAGAGAGAGAGAGAC } \\
\text { GTGTGTGTGTGTGTGT } \\
\text { GTGTGTGTGTGTGTGTC }\end{array}$ \\
\hline
\end{tabular}

$\mathrm{R}=\mathrm{A}+\mathrm{G}$ and $\mathrm{Y}=\mathrm{C}+\mathrm{T}$.

RNA extraction followed the routine CIP CTAB (2\% CTAB, $100 \mathrm{mM}$ Tris$\mathrm{HCl}, \mathrm{pH}$ 8.0, $50 \mathrm{mM}$ EDTA, $\mathrm{pH} 8.0,1.4 \mathrm{M} \mathrm{NaCl}, 2 \%$ PVP-40, $1 \%$ Na sulfite- the last two, add before use) extraction protocol, modified by the bench drill. Briefly, $2 \mathrm{~mL}$ of CTAB extraction buffer was added to $300 \mathrm{mg}$ of leaves in a plastic bag. The tissue was ground with the bench drill and incubated for $10 \mathrm{~min}$. at room temperature (RT). The liquid phase was transferred to $2.0-\mathrm{mL}$ microtubes and incubated at room temperature $\left(26 \pm 2^{\circ} \mathrm{C}\right.$ ) for $15 \mathrm{~min}$. Afterwards, $800 \mu \mathrm{L}$ of the extract was placed into $2.0 \mathrm{~mL}$ microtubes and $800 \mu \mathrm{L}$ of chloroform:isoamyl alcohol (24:1 v:v) added and the mixture centrifuged for $9.000 \mathrm{~g}$ for $10 \mathrm{~min}$. The supernatant $(600 \mu \mathrm{L})$ was transferred into a new microtube and $360 \mu \mathrm{L}$ of isopropanol added, vortexed and kept $-20^{\circ} \mathrm{C}$ for $20 \mathrm{~min}$. Samples were then centrifuged at 9,000 g for $10 \mathrm{~min}$ and the supernatant discarded. The pellet was washed with $70 \%$ ethanol $(700 \mu \mathrm{L})$, and centrifuged at 9,000 $\mathrm{g}$ for $10 \mathrm{~min}$. The ethanol was eliminated, pellets were left to dry at room temperature.

The quality of the nucleic acids (DNA and RNA) obtained was checked by agarose gel electrophoresis, and the amount of DNA/RNA was inferred by comparison with given standards (data not shown). 
Table 2. Plant species, Name, Sequence and Ta of SSR markers used to amplify DNA extracted from six plant species using the bench drill protocol (*Corresponds do ISSR numbers in agarose gels).

\begin{tabular}{|c|c|c|c|c|c|c|c|}
\hline Species & Name SSR & $5^{\prime} \cdot 3^{\prime} \mathrm{F}$ & $5^{\prime} \cdot 3^{\prime} \mathrm{R}$ & $\mathrm{Ta}^{\circ} \mathrm{C}$ & Motif & bp & Reference \\
\hline & $*_{(9) \text { MaCEN11 }}$ & GTTTTGGGTTTAGGCGTTGAAAGCAGCACGCCTTATCTTG & GGCATATCGAGGTGGGTCT & 58 & $(\mathrm{AT})_{s}(\mathrm{AC})_{\mathrm{g}}$ & $205-280$ & Creste et al. (2006) \\
\hline & *(25)MaO-EC12 & CTTGTATTGGGATGAGGAGGAAGATGATGACCCCCACCTC & TATCCCCACCACCCTATCCT & 55 & 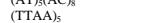 & $220-225$ & Creste et al. (2006) \\
\hline \multirow{4}{*}{ Banana } & $*(27)$ MaO-ED09 & ACCAACCTAGGAAACACAGTGG. & CGTGAAGTGAATGGCAAAA & 57 & & $240-270$ & Creste et al. (2006) \\
\hline & $*(31) \mathrm{MaC}-\mathrm{CEN1}$ & & TTCTCCTTATCCCGTGGTTG & 58 & (TTAA)6 & $285-290$ & Creste et al. (2006) \\
\hline & $*(96)$ MaOCEN03 & $\begin{array}{l}\text { TGAAAATCTCACTGGCATTATTT } \\
\text { GCTGCAGAATTTGAAAGATGG }\end{array}$ & TTCGGGATAGGAGGAGGAG & 55 & $(\mathrm{AGC})_{5}$ & $210-280$ & Creste et al. (2006) \\
\hline & $*(48)$ SSRY49 & TGTGACAATTTTCAGATAGCTTA & TGCAACCATAGTGCCAAGC & 58 & & 300 & . \\
\hline \multirow{5}{*}{ Cassava } & $*(68)$ SSRY 68 & TCTCGATTTGGTTTGGTTCA & CAGCTGGAGGACCAAAAATG & 60 & $(\mathrm{CT}) 12 \mathrm{CC}(\mathrm{CT})_{17}$ & 287 & \\
\hline & $*(83)$ SSRY 82 & CAGGCTCAGGTGAAGTAAAGG & CACCATCGGCATTAAACTTTG & 55 & $\left(\mathrm{GA}_{24}\right.$ & 211 & \\
\hline & $\begin{array}{l}*_{*}^{*}(170) \text { SSRPY170 } \\
*_{(1799) S S Y 179}\end{array}$ & TCCACAGATTGCCCATTA & $\begin{array}{l}\text { TCATCCTTGTTGCAGGGTTA } \\
\text { GCGAAGTAAGTTACAACTTTTCTA }\end{array}$ & $\begin{array}{l}50 \\
55\end{array}$ & $\begin{array}{l}(\mathrm{TAA}) 5(\mathrm{~N}) 7 \\
(\mathrm{GA})\end{array}$ & 2299 & : \\
\hline & & $\begin{array}{l}\text { GGA TGA AAA ATG CTC AAA ATG } \\
\text { ATCACAATACTAGCAGCGCC }\end{array}$ & & & & & \\
\hline & $\begin{array}{l}{ }^{*}(24) \mathrm{C} 108 \mathrm{~B} 05 \\
* \text { *(6)TA27 }\end{array}$ & $\begin{array}{l}\text { ATCAAAATTACAAGCAGCGCC } \\
\text { ACGGTGCGTTTGAGGTAG }\end{array}$ & $\begin{array}{l}\text { CCCTAAAAACCAAGTACACA } \\
\text { TAGTACCCACAGGCAAGAGA }\end{array}$ & ${ }_{54}^{54}$ & $\begin{array}{l}\text { (GA) } \\
\mathrm{TAA}_{14}\end{array}$ & $\begin{array}{l}148-182 \\
200-700\end{array}$ & $\begin{array}{l}\text { Frolichere ta al. (2008) } \\
\text { Kijas et al. (1997) }\end{array}$ \\
\hline \multirow[t]{4}{*}{ Citrus } & $*(74) \mathrm{CAC} 23$ & ATTGCTGAACATAATCCGCG & 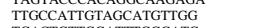 & 55 & CAC & $90-250$ & $\begin{array}{l}\text { Kijas et al. (1997) } \\
\text { Kong }\end{array}$ \\
\hline & $*(39) \mathrm{CT} 02$ & & TGACTGTTGGATTTGGGATG & 54 & $\mathrm{CT}$ & $102-144$ & Barkley et al. (2006) \\
\hline & $*^{*}(47)$ cAGG9 & $\begin{array}{l}\text { GATTGGTGCCGGGAGATTA } \\
\text { GGGAGGGAGAGGAACGAG }\end{array}$ & TGCCTTGCTCTCCACTCC & 55 & AGG & & Barkley et al. (2006) \\
\hline & ${ }^{*}(34)$ CPMini-34F & CCTTGTGATTCATGATTTAGGG & & 58 & & 870 & Oliveira et al. (2015) \\
\hline \multirow{4}{*}{ Papaya } & & & $\begin{array}{l}\text { GGTTTGGCATGGGGTTATT } \\
\end{array}$ & & $(\text { TAAGCAT) })_{8}$ & $280-300$ & Oliveira et al. (2015) \\
\hline & $\begin{array}{l}*(42) \text { CPMini- }-42 \\
*(44) \text { CPMini-44 }\end{array}$ & CACATGTAAAACCCGTGAGG & 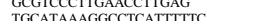 & $\begin{array}{r}58 \\
58\end{array}$ & $\begin{array}{l}(\text { GGGAGAG)s } \\
\text { (GTTAGGGTTAGAGT }\end{array}$ & $\begin{array}{l}260-280 \\
38-390\end{array}$ & Oliveira et al. (2015) \\
\hline & $*(46)$ CPMini-46 & $\begin{array}{l}\text { GGGCCTTTATCCATGTTTGA } \\
\text { ATCGGGGTTCGCTTATTTG }\end{array}$ & $\begin{array}{l}\text { GTCTTGACACAACCCAAA } \\
\text { CTAATTCTTGACGGCAATGA }\end{array}$ & 57 & $\begin{array}{l}\text { TAATG } 6 \\
(\text { AAATAAA })_{6}\end{array}$ & $320-355$ & Oliveira et al. (2015) \\
\hline & ${ }^{*}(41)$ PE41 & CCATAGTCCCAACAAGCATC & GGA $A T C C G A \triangle A C T$ GTTTG & 60 & $\left(\right.$ TTTTTAT) $_{6}$ & $205-280$ & Oliveira et al. (2005) \\
\hline \multirow{5}{*}{ Passionfruit } & $\begin{array}{l}* 099 \mathrm{PE} 99 \\
*(66) \mathrm{PE} 66\end{array}$ & $\begin{array}{l}\text { CTTCAGGGTCACACACATT } \\
\text { TCAGGAAGATGCATGTAGT }\end{array}$ & $\begin{array}{l}\text { GGAAAICGAAAACGGITG } \\
\text { CGTTCATCCTTTAGTGGCTA }\end{array}$ & $\begin{array}{l}60 \\
60\end{array}$ & $(A T) \cdot(A C)$ & $\begin{array}{l}220-225 \\
240-270\end{array}$ & $\begin{array}{l}\text { Oliveira et al. (2013) } \\
\text { Oleveira elal }\end{array}$ \\
\hline & $*(88)$ PE8 88 & & GCTGTGGACCCTAACTCAGTC & 60 & 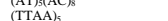 & $\begin{array}{l}240-270 \\
285-290\end{array}$ & Oliveira et al. (2013) \\
\hline & $*(99)$ PE99 & $\begin{array}{l}\text { GGTAAAGTGTGTGTGTGTGT } \\
\text { TTGAGAGCCAGAGGGTTTTGAGTAATCGGCGGCGTGTC }\end{array}$ & $\begin{array}{l}\text { GTTCATCCTTTAGTGGGCT } \\
\text { CTGGGTTTTGTTTATGTTGC }\end{array}$ & 60 & $\begin{array}{l}(\mathrm{ACC})_{9} \\
\text { (TTAA) }\end{array}$ & $210-280$ & Oliveira et al. (2013) \\
\hline & $*_{(05) \text { ACUMS } 217}$ & GACGAGGACCGTACTCACGA & TTACCATCAAAAGGGCATGA & 53 & & 224 & Kinsuat \& Kummar (2007) \\
\hline & *(11)ACLR749 & & ACGGTCCGATGTAAAATTCG & 49 & $(\mathrm{GT})_{11}$ & 180 & Kinsuat \& Kummar (2007) \\
\hline \multirow{2}{*}{ Pineapple } & ${ }^{*}(15)$ ACLR776B & & GGAGGGCGAGAGAGAGAG & 50 & $(\mathrm{AG})_{2}(\mathrm{GA})_{2}(\mathrm{G})_{2}^{*}$ & 220 & Kinsuat \& Kummar (2007) \\
\hline & 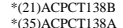 & & $\begin{array}{l}\text { GTTCGAGAGAGAAGAGAGAGA } \\
\text { ATGGCATGATCTCGTCCACT }\end{array}$ & $\begin{array}{l}48 \\
58\end{array}$ & 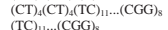 & $\begin{array}{l}191 \\
161\end{array}$ & Kinsuat \& Kummar (2007) \\
\hline
\end{tabular}

RNA extraction profiles of leaves of the six species and roots of four species using the bench drill protocol are shown in Figure 3.

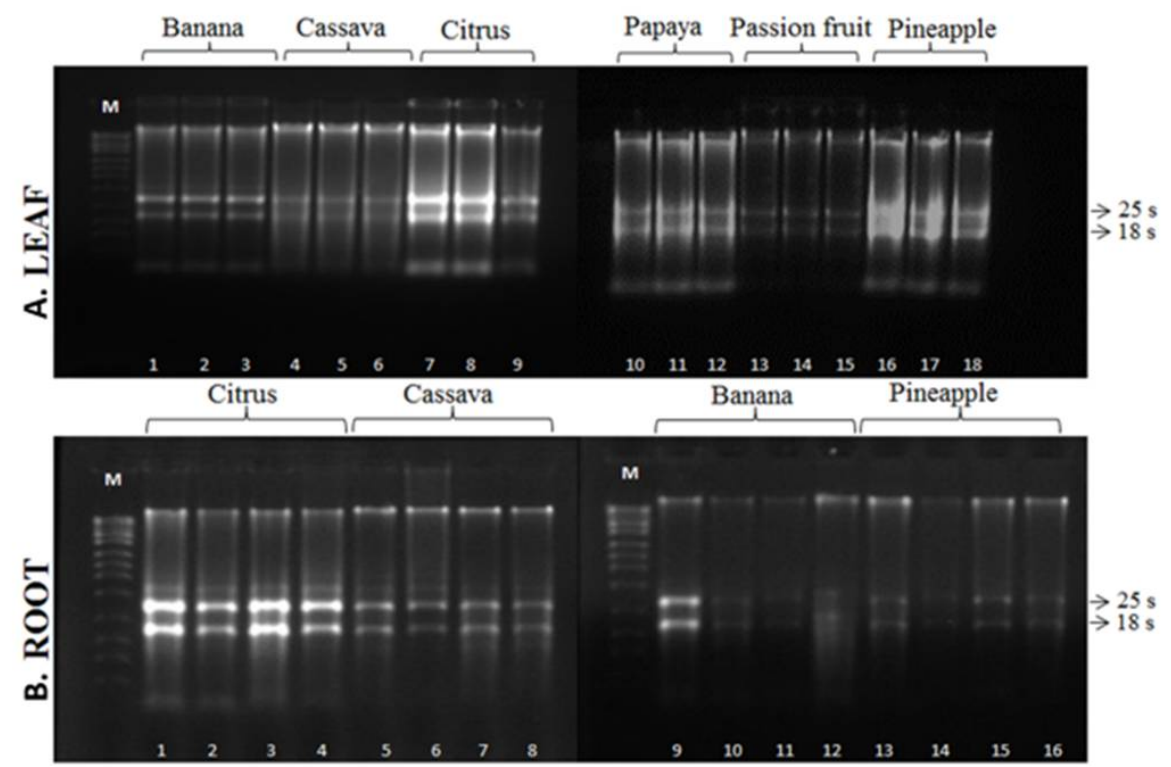

Figure 3. Eletrophoretic profile of RNA ( $\left.200 \mathrm{ng} . \mu \mathrm{L}^{-1}\right)$ extracted from A) leaves of the six plant species: Banana, cassava, citrus, papaya, passion fruit and pineapple and B) RNA extracted from roots of citrus, cassava, banana and pineapple using the bench drill protocol in $1 \%$ agarose gel. $\mathrm{M}=1 \mathrm{~kb}$ ladder (Invitrogen). $25 \mathrm{~s}$ and $18 \mathrm{~s}$ ribosomal RNA. 


\section{RESULTS AND DISCUSSION}

This bench drill protocol was possible by uniting protocols from CIRAD (Montpellier, France) and CIP (Lima, Peru) and given our experience, we believe that a molecular biology laboratory may save between USD $\$ 20,000.00$ to 30,000.00/year, just by eliminating the cost of liquid nitrogen. The use of this protocol in the different species permitted satisfactory amplification of ISSR (Table 1) and SSR (Table 2) markers as shown in Figures 4 and 5.
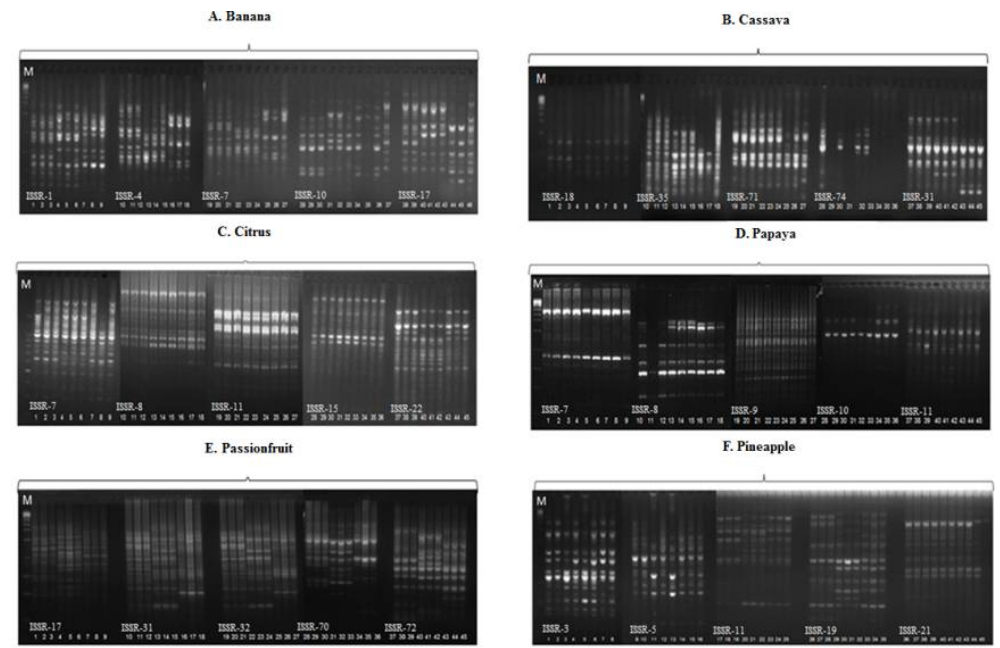

Figure 4. Electrophoretic profiles of DNA amplified with five ISSR markers in $2.0 \%$ agarose gel electrophoresis. A: Banana, B: Cassava, C: Citrus, D: Papaya, E: Passion fruit, and F: Pineapple (three replicates of three different genotypes of each species). $M=1 \mathrm{~kb}$ ladder (Invitrogen).

A. Banana

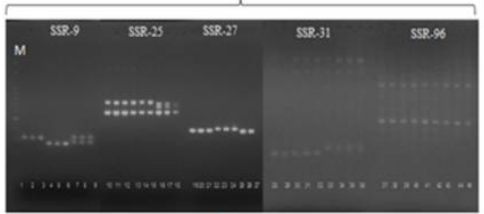

c. Citrus

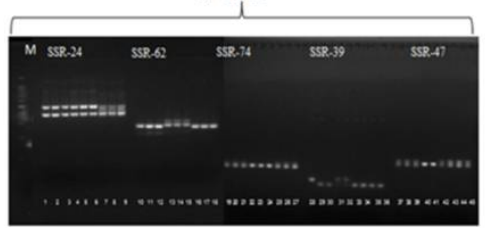

E. Passion fruit

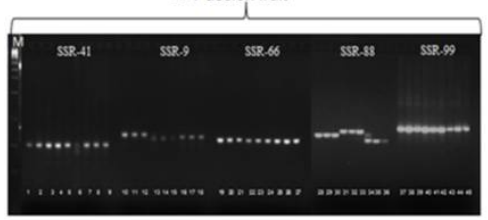

B. Cassava

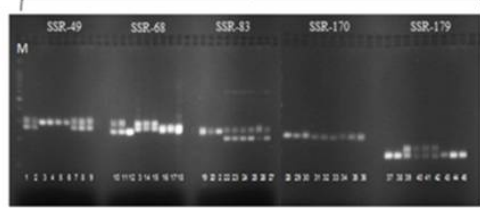

D. Papaya

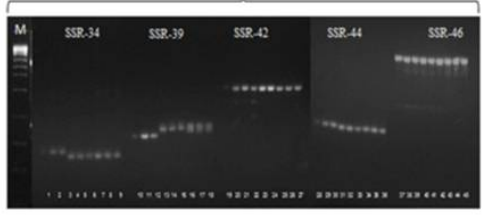

F. Pineapple

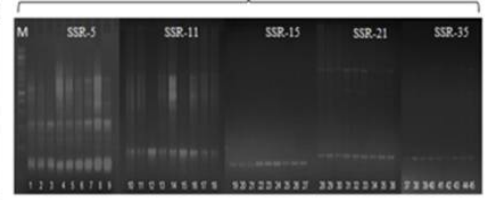

Figure 5. Electrophoretic profiles of DNA amplified with SSR markers on 3.0\% agarose gels. DNA templates were extracted from leaves with the bench drill protocol. A- Banana, B- Cassava, C- Citrus, D- Papaya, E- Passion fruit and FPineapple. $\mathrm{M}=1 \mathrm{~kb}$ ladder (Invitrogen). 
In order to verify the shelf life of the RNA of the six plant species and its integrity, pellets were left at room temperature and RNA quality checked in $0.8 \%$ agarose gel (Figure 6).

Except for cassava, the quality of the RNA molecules after three weeks at room temperature was maintained. Therefore, we believe our protocol will bring another option to laboratories that make use of DNA and RNA routine analysis/extraction, by providing a quick, easy and reliable method of nucleic acid extraction for a wide range of species at a very low cost/sample.
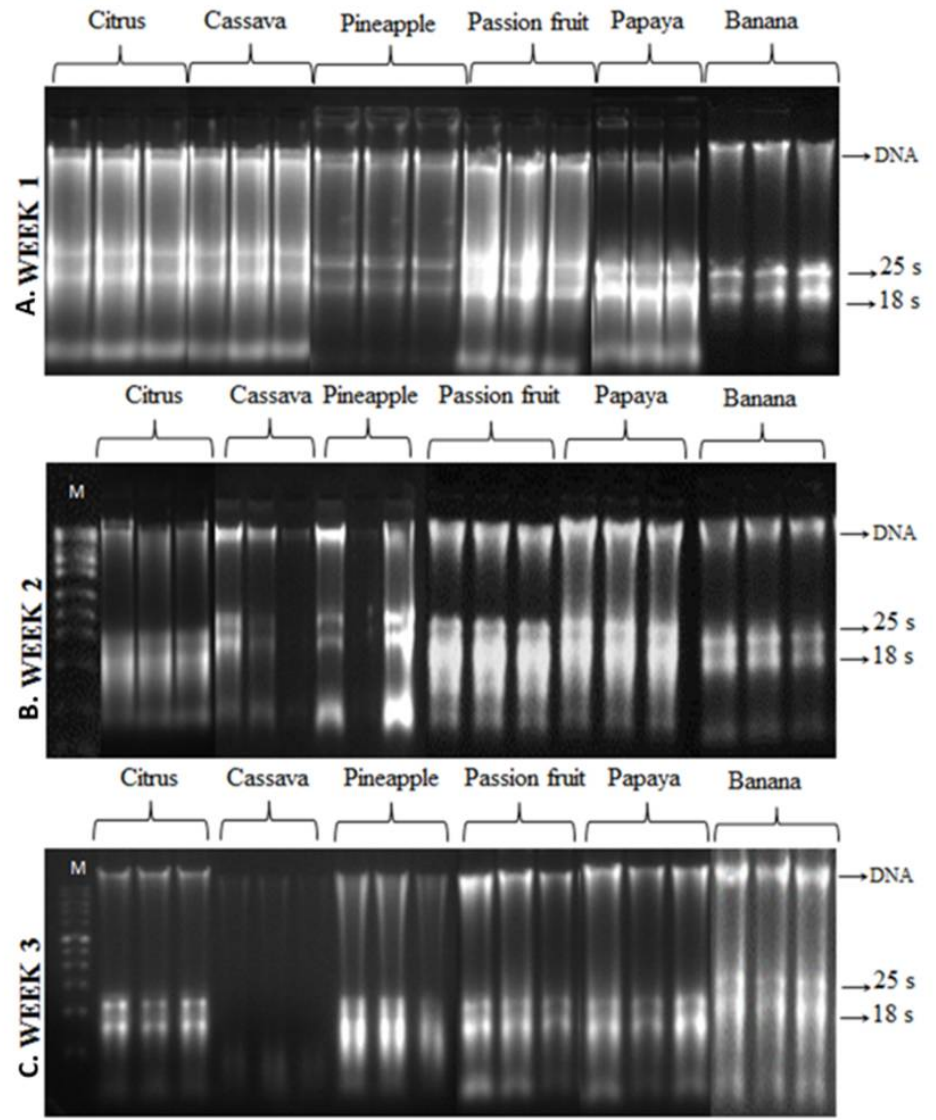

Figure 6. Electrophoretic profile of RNA $(5 \mu \mathrm{L})$ extracted from leaves of six plant species (citrus, cassava, pineapple, passion fruit, papaya and banana) using the bench drill protocol without DNase treatment. $A=$ Week 1 = RNA left for a week at room temperature; B) Week $2=$ RNA left for two weeks at RT; C) Week $3=$ RNA left at room temperature for three weeks. $\mathrm{M}=1 \mathrm{~kb}$ ladder (Invitrogen). $25 \mathrm{~s}$ and $18 \mathrm{~s}$ - ribosomal RNA.

\section{ACKNOWLEDGMENTS}

The authors would like to thank the support from Embrapa Mandioca e Fruticultura, the Bill and Melinda Gates Foundation, Fundação de Amparo à Pesquisa do Estado da Bahia (FAPESB) and Conselho Nacional do Desenvolvimento Científico e Tecnológico (CNPq). 


\title{
CONFLICTS OF INTEREST
}

\author{
The authors declare no conflict of interest.
}

\section{REFERENCES}

Barkley NA, Roose ML, Krueger RR and Federeci CT (2006). Assessing genetic diversity and population structure in a citrus germplasm collection utilizing simple sequence repeat markers (SSRs). Theor. Appl. Genet. 112: 1519-1531. DOI 10.1007/s00122-006-0255-9.

Creste S, Benatti TR, Orsi MR, Risterucci A-M, et al. (2005). Isolation and characterization of microsatellite loci from a commercial cultivar of Musa acuminate. Molecular Ecology Notes. DOI: 10.1111/j.1471-8286.2005.01209.x.

Doyle JJ and Doyle JL (1990). Isolation of plant DNA from fresh tissue. Focus. 12: 13-15.

Ferdous J, Hanafi MM, Rafii MY and Muhammad K (2012). A quick DNA extraction protocol: Without liquid nitrogen in ambient temperature. Afr. J. Biotecnol. 11: 6956-6964. DOI: 10.5897/AJB11.3283.

Froelicher Y, Dambier D, Bassene JB, Constantino G, et al. (2008). Characterization of microsatellite markers in mandarin. Molecular Ecology Resources. DOI: 10.1111/j.1471-8286.2007.01893.x

Kijas JMH, Thomas MR, Fowler JCS and Roose ML (1997). Integration of trinucleotide microsatellites into a linkage map of citrus. Theor. Appl. Genet. 94: 701-806.

Kinsuat MJ and Kumar (2007). Polymorphic microsatellite and cryptic simple repeat sequence markers in pineapples (Ananas comosus var. comosus). Molecular Ecology Notes. 7: 1032-1035. DOI: 10.1111/j.14718286.2007.01764.x.

Oliveira GAF, Dantas JLL and Oliveira EJ (2015). Development and validation of minisatellite markers for Carica papaya. Biologia Plantarum. 59: 686-694.

Oliveira EJ, Padua JG, Zucchi MI, Camargo LEA, et al. (2005). Development and characterization of microsatellite markers from the yellow passion fruit (Passiflora edulis f. flavicarpa). Molecular Ecology Notes. 5: 331-333.

Oliveira GAF, Paduar JG, Costa JL, Jesus ON, et al. (2013). Cross-species amplification of microsatellite loci developed for Passiflora edulis Sims. in related Passiflora Species. Braz. Arch. of Biol. and Tech. 56: 785-792.

Sahu SK, Thangaraj M and Kathiresan K (2012). DNA extraction protocol for plants with high levels of secondary metabolites and polysaccharides without using liquid nitrogen and phenol. Molecular Biology. doi:10.5402/2012/205049. 